\title{
Induction of Labour: Change of Method and its Effects
}

\author{
Geburtseinleitung: Änderung des Regimes und ihre Effekte
}

Authors

Affiliations
S. Kehl ${ }^{1}$, C. Weiss ${ }^{2}$, U. Dammer ${ }^{1}$, E. Raabe ${ }^{1}$, S. Burghaus ${ }^{1}$, J. Heimrich ${ }^{1}$, J. Hackl ${ }^{1}$, M. Winkler ${ }^{1}$, M. W. Beckmann ${ }^{1}$, F. Faschingbauer

${ }^{1}$ Frauenklinik, Universitätsklinikum Erlangen, Erlangen

${ }^{2}$ Abteilung für Medizinische Statistik, Biomathematik und Informationsverarbeitung, Universitätsmedizin Mannheim, Universität Heidelberg, Mannheim

\section{Key words \\ induction of labour \\ - balloon catheter \\ - misoprostol \\ - efficacy \\ - dinoprostone \\ - method \\ Schlüsselwörter \\ - Geburtseinleitung \\ - Ballonkatheter \\ - Misoprostol \\ - Effektivität \\ - Dinoproston \\ - Regime}

Deutschsprachige Zusatzinformationen online abrufbar unter: www.thieme-connect.de/ ejournals/toc/gebfra

received $\quad 9.12 .2014$ revised 28.1.2015 accepted 28.1.2015

\section{Bibliography}

DOI http://dx.doi.org/ 10.1055/s-0035-1545899 Geburtsh Frauenheilk 2015; 75 : 238-243 @ Georg Thieme Verlag KG Stuttgart · New York . ISSN 0016-5751

\section{Correspondence}

PD Dr. Sven Kehl

Universitätsklinikum Erlangen Frauenklinik

Universitätsstraße 21-23

91054 Erlangen

sven.keh|@uk-erlangen.de

\section{Abstract \\ V}

Aim: The combination of mechanical and drug procedures for the induction of labour seems to be beneficial. Accordingly, the normal procedure in clinical routine has been changed and induction of labour by means of a balloon catheter has been implemented. The aim of this study was to find out if this procedural change has resulted in a more effective induction of labour.

Materials and Method: In this historical cohort study 230 inductions of labour at term in the year 2012 were compared with 291 inductions of labour in the year 2013, all at the University of Erlangen Perinatal Centre. Exclusion criteria were, among others, a multiple pregnancy, a premature rupture of membranes and a prior Caesarean section. In 2012 births were induced solely by use of the drugs dinoprostone and misoprostol, in 2013 not only with misoprostol but also mainly by use of a balloon catheter. The primary target parameter was the rate of failed labour inductions, defined as "no birth within 72 hours".

Results: Altogether 521 inductions of labour were analysed. The rate of failed inductions of labour could be reduced by the changes in induction method (first-time mothers: 23 vs. 9\%, $\mathrm{p}=0.0059$; multiparous women: 10 vs. $1 \%$, $\mathrm{p}=0.0204$ ). Furthermore, the rate of primary Caesarean sections due to failed induction of labour (5.7 vs. $1.4 \%, p=0.0064$ ), that of the observation of green amniotic fluid (first-time mothers: 23 vs. $9 \%, p=0.0059$; multiparous women: 10 vs. $1 \%, p=0.0204$ ) and of infantile infections (firsttime mothers: 23 vs. $9 \%, p=0.0059$; multiparous women: 10 vs. $1 \%, \mathrm{p}=0.0204$ ) were all reduced as well.

Conclusion: The routine use of a balloon catheter for induction of labour has markedly improved the procedure. There were fewer failed labour inductions and fewer Caesarean sections due to failed induction of labour.

\section{Zusammenfassung \\ $\nabla$}

Ziel: Die Kombination mechanischer und medikamentöser Verfahren zur Geburtseinleitung scheint vorteilhaft zu sein. Daher wurde das routinemäßige Vorgehen im klinischen Alltag geändert und die Geburtseinleitung mit Ballonkathetern implementiert. Ziel dieser Studie war es herauszufinden, ob diese Änderung zu einer effektiveren Geburtseinleitung geführt hat.

Material und Methode: In dieser historischen Kohortenstudie wurden 230 Geburtseinleitungen am Termin des Jahres 2012 mit 291 Geburtseinleitungen aus dem Jahr 2013, die am Universitäts-Perinatalzentrum Erlangen durchgeführt wurden, verglichen. Ausschlusskriterien waren u. a. eine Mehrlingsschwangerschaft, ein vorzeitiger Blasensprung und ein vorheriger Kaiserschnitt. Im Jahr 2012 wurden Geburten ausschließlich medikamentös mit Dinoproston und Misoprostol eingeleitet, 2013 neben Misoprostol vorwiegend mit Ballonkathetern. Der primäre Zielparameter war die Rate an frustranen Geburtseinleitungen, definiert als „keine Geburt innerhalb 72 Stunden“.

Ergebnis: Insgesamt wurden 521 Geburtseinleitungen analysiert. Die Rate an frustranen Geburtseinleitungen konnte durch die Umstellung des Einleitungsregimes verringert werden (Erstgebärende: 23 vs. 9\%, p=0,0059; Mehrgebärende: 10 vs. $1 \%, p=0,0204)$. Reduziert wurden weiterhin die Rate an primären Kaiserschnitten wegen einer frustranen Geburtseinleitung (5,7 vs. $1,4 \%, p=0,0064)$, das Auftreten von grünem Fruchtwasser (Erstgebärende: 23 vs. 9\%, $\mathrm{p}=0,0059$; Mehrgebärende: 10 vs. $1 \%, \mathrm{p}=0,0204$ ) und von kindlichen Infektionen (Erstgebärende: 23 vs. $9 \%, p=0,0059$; Mehrgebärende: 10 vs. $1 \%$, $\mathrm{p}=0,0204)$.

Schlussfolgerung: Die routinemäßige Verwendung von Ballonkathetern zur Geburtseinleitung verbesserte die Geburtseinleitung. Es kam zu we- 
niger frustranen Geburtseinleitungen und $\mathrm{zu}$ weniger Kaiserschnitten wegen einer frustranen Geburtseinleitung.

\section{Introduction}

The induction of labour is nowadays part of the daily obstetric routine and is performed in ever increasing numbers of cases [1]. There are more and more situations in which induction of labour is preferred over non-operative procedures [2,3]. However, this means that one is increasingly faced with immature cervix findings - and this is associated with a poorer chance of success for labour induction [4-8]. Effective methods for the induction of labour are thus more important than ever. In cases of immature cervix findings, oxytocin is inferior to prostaglandins and should not be used as a sole method [9]. Prostaglandins are available in different forms: as prostaglandin E2 (dinoprostone) or as a synthetic prostaglandin E1 analogue (misoprostol), for vaginal or oral administration. In such cases misoprostol appears to be the more effective drug - and should preferably be administered orally $[10,11]$. Mechanical methods for the induction of labour such as use of balloon catheters are frequently used internationally and are also attracting more attention in Germany. They are just as effective as prostaglandin and lead to less overstimulation. However, oxytocin is more frequently needed to stimulate contractions after use of a balloon catheter [12-14]. Induction of labour appears to be particularly effective when not only a balloon catheter but also prostaglandins are used together [12,15-17]. On the basis of these new data, the Department of Gynaecology and Obstetrics at the University Hospital in Erlangen has changed its induction methods: Beside the to date mainly administered prostaglandins, balloon catheters are now being used in the daily routine. In addition, the doses and administration intervals for misoprostol have been increased. The aim of the present contribution is to determine whether this change has resulted in an improved induction of labour.

\section{Materials and Method}

\section{$\nabla$}

\section{Inclusion and exclusion criteria}

In this historical cohort study inductions of labour at term ( $\geq 37+0$ week of pregnancy) in the years 2012 and 2013 were included. Excluded were multiple gravidities, a prior Caesarean section in the case history, foetal breech presentation, intrauterine foetal death and structural or chromosomal anomalies. Also inductions of labour following a premature rupture of membranes were not included since these are already associated with a high success rate for induction of labour [12,15-17]. The gestational age was determined on the basis of the last menstrual bleeding corrected, if necessary, according to the crown-rump length [18].

\section{Description of the induction methods}

In order to demonstrate possible effects of the change in induction methods on the clinical routine, the inductions of labour of the year 2012 were compared with those of 2013. Whereas in 2012 labour was induced exclusively with the help of drugs with dinoprostone (vaginal gel and vaginal insert) and oral misoprostol - in 2013 balloon catheters (Cook Medical, Cervical Ripening Balloon; Cook OB/GYN, Bloomington, Indiana, USA) and also oral misoprostol were used routinely. Misoprostol was admin- istered in 2012 on the whole in lower doses and at longer intervals. On the first day a dose of $50 \mu$ g orally and, if necessary, one of $100 \mu \mathrm{g} 6$ hours later were given. On the second day the drug was administered vaginally - initially with $25 \mu \mathrm{g}$ and in the absence of normal onset of birth another $50 \mu$ gafter 6 hours. On the third day a maximum of 3 doses of $50 \mu \mathrm{g}$ were given vaginally at 6 hour intervals. In the year 2013 misoprostol was administered every 4 hours; on the first day a maximum of 3 doses of $50 \mu \mathrm{g}$ orally, on the second day doses of $100 \mu \mathrm{g}$. On the third day a maximum of 3 doses of $100 \mu \mathrm{g}$ were administered vaginally.

\section{Primary and secondary target parameters}

The primary target parameter was the rate of failed induction of labour defined as "no birth within 72 hours after start of induction". Further target criteria were the rate of Caesarean scetions, the rate of Caesarean sections due to failed induction of labour and the rates of birth within 24 and 48 hours. In order to detect possible effects on the course of birth as well as to assess the outcome of the baby, the following parameters were analysed: arterial umbilical cord $\mathrm{pH}$ value $<7.10$, arterial umbilical cord base deficit (base excess, BE) $<-12.0 \mathrm{mmol} / \mathrm{L}$, Apgar value after $5 \mathrm{~min}$ utes $<7$, pathological cardiotocography (CTG), green amniotic fluid and postpartum transfer to a neonatal clinic.

\section{Statistical analysis}

All statistical calculations and analyses were performed using the statistical software SAS, release 9.3 (SAS Institute Inc., Cary, North Carolina, USA). For nominally scaled variables absolute and relative frequencies are given; quantitatively near normally distributed variables are presented as mean values and standard deviations as well as minimum and maximum values. For ordinally scaled and quantitatively discrete variables the median value is given in addition to the mean value. $\mathrm{A} \mathrm{X}^{2}$ test was applied for the comparison of two groups with regard to a nominally scaled variable or - when the prerequisites were not fulfilled - Fisher's exact test was used. The comparison of mean values of two groups was made using the t test for two unpaired samples. For ordinally scaled or quantitatively discreet variables the MannWhitney U test was employed. All tests were two-sided. The results were considered to be significant when the $\mathrm{p}$ value was less than 0.05 .

\section{Results}

$\nabla$

\section{Demographic parameters}

In the investigated period there were 4565 births, under consideration of the inclusion and exclusion criteria 521 of these were included in this study. The demographic parameters are presented in Table 1. Apart from a minimally more mature cervix finding in 2013 (Bishop score 2012 in median 1 [0-6] vs. 20132 [0$10], \mathrm{p}<0.0001)$ there were no significant differences.

\section{Methods for induction of labour}

The methods for the induction of labour changed significantly during the investigated period. In 2012 labour was induced in the collective under investigation exclusively by means of drugs. In 49 cases $(21.3 \%)$ dinoprostone vaginal inserts were used as 
Table 1 Demographic details. Quantitative variables are given as mean value \pm standard deviation, ordinally scaled varables are described as median as well as extreme values (in parenthesis). For the qualitative variables absolute and relative frequencies are given.

\begin{tabular}{|c|c|c|c|}
\hline & $2012(n=230)$ & $2013(n=291)$ & $\mathrm{p}$ value \\
\hline Age (years) & $30.9 \pm 5.2(16-46)$ & $31.0 \pm 5.02(17-44)$ & 0.8046 \\
\hline Body mass index & $25.7 \pm 4.9(17.3-51.3)$ & $25.1 \pm 6.0(16.6-51.4)$ & 0.2426 \\
\hline Gravidity & $2(1-8)$ & $1(1-12)$ & 0.4641 \\
\hline Parity (without the current pregnancy) & $0(0-5)$ & $0(0-4)$ & 0.1671 \\
\hline Gestational age (days) & $283.3 \pm 8.0(260-298)$ & $283.8 \pm 8.2(260-299)$ & 0.4996 \\
\hline Bishop score & $1(0-6)$ & $2(0-10)$ & $<0.0001$ \\
\hline Birth weight (g) & $3490.5 \pm 484.0(2030-5400)$ & $3511.8 \pm 492.4(1840-4950)$ & 0.6216 \\
\hline \multicolumn{4}{|l|}{ Gender } \\
\hline - Female & $110(47.8 \%)$ & $159(55.2 \%)$ & 0.0948 \\
\hline - Male & $120(52.3 \%)$ & $129(44.8 \%)$ & \\
\hline \multicolumn{4}{|l|}{ Risk factors } \\
\hline - Hypertensive disease of pregnancy & $28(11.7 \%)$ & $31(10.7 \%)$ & 0.6955 \\
\hline - Gestational diabetes & $33(14.4 \%)$ & $44(15.1 \%)$ & 0.8051 \\
\hline - Intrahepatic cholestasis of pregnancy & $5(2.2 \%)$ & $5(1.7 \%)$ & 0.7557 \\
\hline - Intrauterine growth retardation & $10(4.4 \%)$ & $11(3.8 \%)$ & 0.7435 \\
\hline \multicolumn{4}{|l|}{ Mode of induction } \\
\hline$\rightarrow \mathrm{CRB}$ & 0 & $49(16.8 \%)$ & $<0.0001$ \\
\hline - CRB/dinoprostone vaginal gel & 0 & $7(2.4 \%)$ & 0.0195 \\
\hline - CRB/misoprostol & $2(0.9 \%)$ & $160(55.0 \%)$ & $<0.0001$ \\
\hline - CRB/dinoprostone vaginal gel/misoprostol & 0 & $6(2.1 \%)$ & 0.0368 \\
\hline - Dinoprostone vaginal gel & $25(10.9 \%)$ & $3(1.0 \%)$ & $<0.0001$ \\
\hline - Dinoprostone vaginal gel/misoprostol & $17(7.4 \%)$ & $1(0.3 \%)$ & $<0.0001$ \\
\hline - Dinoprostone vaginal gel/insert & $11(4.8 \%)$ & 0 & 0.0001 \\
\hline - Misoprostol & $131(57.0 \%)$ & $62(21.3 \%)$ & $<0.0001$ \\
\hline - Misoprostol/dinoprostone vaginal gel/insert & $6(2.6 \%)$ & 0 & 0.0071 \\
\hline - Misoprostol/dinoprostone vaginal insert & $5(2.2 \%)$ & $1(0.3 \%)$ & 0.0922 \\
\hline Oxytocin & $6(2.6 \%)$ & $2(0.7 \%)$ & 0.1469 \\
\hline - Dinoprostone vaginal insert & $27(11.7 \%)$ & 0 & $<0.0001$ \\
\hline
\end{tabular}

CRB: Cervical ripening balloon (balloon catheter)

compared to a single case in $2013(0.3 \%, \mathrm{p}<0.0001)$. In 2012 no balloon catheters were used whereas in 2013 they were used in $76.3 \%(n=222)$ of the cases of induced labour. Misoprostol and dinoprostone vaginal gel were used more frequently in 2012 as the sole drug $(n=131$ [57.0\%] vs. 62 [21.3\%], $\mathrm{p}<0.0001$ and 25 [10.9\%] vs. 3 [1.0\%], p < 0.0001). Oxytocin was only rarely used as the sole drug in both years (6 [2.6\%] vs. 2 [0.7\%], $\mathrm{p}=0.1469)$.

\section{Indications for induction of labour}

In both years induction of labour was employed mostly for exceeding the term date (51.3 and 54\%). With regard to the other indications, there were also hardly any differences between the two years ( $\bullet$ Table 2 ). As sole exception, labour was induced at the patient's request more often in 2013 (12 [5.2\%] vs. 34 [11.7\%], p=0.0098).

\section{Primary and secondary target parameters}

The results of the various target parameters are presented in - Table 3. The rate of failed inductions of labour could be minimised by the change in the induction method (first-time mothers: 23 vs. $9 \%, p=0.0059$; multiparous women: 10 vs. $1 \%$, $\mathrm{p}=0.0204$ ). Furthermore, the rate of occurrence of green amniotic fluid was also reduced (first-time mothers: 16 vs. 3\%, $\mathrm{p}=0.0002$; multiparous women: 8 vs. $0 \%, \mathrm{p}=0.0035$ ) as was the rate of primary Caesarean sections due to a failed induction of labour (5.7 vs. $1.4 \%, p=0.0064$; $\bigcirc$ Table 4 ). The change of induction method did not have any significant effects on the other secondary target parameters. Thus, for example, the Caesarean section rate $(\mathrm{p}=0.8306)$ and the rates of births at $<24$ or 48 hours $(p=0.2200, p=0.3751)$ for first-time mothers were not different.

\section{Further outcome parameters}

The rate of infantile infections was significantly reduced (firsttime mothers: 8 vs. $0 \%, p=0.0002$; multiparous women: 7 vs. $0 \%, p=0.0079$ ); however, this was not accompanied with a lower rate of transfers to a neonatal unit (first-time mothers: $\mathrm{p}=0.0604$; multiparous women: $\mathrm{p}=0.3615$ ). On the whole the outcomes for the babies were very good: only 2 infants had an umbilical cord $\mathrm{pH}$ value $<7.10$ and only three each an umbilical cord $\mathrm{BE}$ value $<-12 \mathrm{mmol} / \mathrm{L}$ or an Apgar value $<7$. Amniotomies, use of peridural anaesthesia and administration of oxytocin were applied in similar frequencies in both years. Under the higher doses of misoprostol used in 2013 no higher rate of CTG pathologies was noticed (first time mother: $p=0.6588$; multiparous women: $\mathrm{p}=0.8421$ )

\section{Discussion}

$\nabla$

There are various methods for the induction of labour but, however, no general consensus as to which method is best. Different factors such as the clinical outcome (e.g., the rate of Caesarean sections), the safety profile, economic points of view and the wishes of the patient must be taken into consideration. In the past few years the induction of labour has been employed more and more generously so that one is faced with more and more 
Table 2 Indication for induction of labour.

\begin{tabular}{|c|c|c|c|}
\hline Indication & $2012(n=230)$ & $2013(n=291)$ & P value \\
\hline Exceeding term date & $118(51.3 \%)$ & $157(54.0 \%)$ & 0.5478 \\
\hline Gestational diabetes & $26(11.3 \%)$ & $31(10.7 \%)$ & 0.8130 \\
\hline Oligohydramnios & $11(4.8 \%)$ & $18(6.2 \%)$ & 0.4879 \\
\hline Suspected/pathological CTG & $5(2.2 \%)$ & $1(0.3 \%)$ & 0.0922 \\
\hline Suspected foetal macrosomia & $12(5.2 \%)$ & $7(2.4 \%)$ & 0.0891 \\
\hline $\begin{array}{l}\text { Hypertensive diseases of pregnancy (chronic hypertension, } \\
\text { gestational hypertension, HELLP, preeclampsia) }\end{array}$ & $20(8.7 \%)$ & $21(7.2 \%)$ & 0.5335 \\
\hline On request & $12(5.2 \%)$ & $34(11.7 \%)$ & 0.0098 \\
\hline Placental insufficiency, intrauterine growth retardation & $10(4.3 \%)$ & $11(3.8 \%)$ & 0.7435 \\
\hline Cholestasis of pregnancy & $4(1.7 \%)$ & $4(1.4 \%)$ & 0.7364 \\
\hline Diminishing foetal movements & $2(0.9 \%)$ & 0 & 0.1944 \\
\hline Others & $10(4.3 \%)$ & $7(2.4 \%)$ & 0.2153 \\
\hline
\end{tabular}

Table 3 Outcome parameters.

\begin{tabular}{|c|c|c|c|c|c|c|}
\hline \multirow[t]{2}{*}{ Target parameter } & \multicolumn{3}{|c|}{ First-time mothers (para $=0$ ) } & \multicolumn{3}{|c|}{ Multiparous women (para $\geq 1$ ) } \\
\hline & $2012(n=137)$ & $2013(n=189)$ & $\mathrm{p}$ value & $2012(n=93)$ & $2013(n=102)$ & $\mathrm{p}$ value \\
\hline Failed induction of labour (no birth $<72 \mathrm{~h}$ ) & $22(23 \%)$ & $9(9 \%)$ & 0.0059 & $9(10 \%)$ & $1(1.3 \%)$ & 0.0204 \\
\hline \multicolumn{7}{|l|}{ Mode of birth $(\mathrm{n}, \%)^{* *}$} \\
\hline - Spontaneous birth & $60(52.2 \%)$ & $90(50.0 \%)$ & 0.8306 & 78 (93\%) & $94(93 \%)$ & 0.7450 \\
\hline - Vaginal-operative birth & $15(13.0 \%)$ & $28(15.6 \%)$ & & $3(4 \%)$ & $2(2 \%)$ & \\
\hline - Caesarean section & $40(34.8 \%)$ & $62(34.4 \%)$ & & $3(4 \%)$ & $5(5 \%)$ & \\
\hline Vaginal birth $<24$ hours $(n, \%)^{*}$ & $34(40 \%)$ & $49(49 \%)$ & 0.2200 & $62(70 \%)$ & $54(68 \%)$ & 0.8547 \\
\hline Vaginal birth $<48$ hours $(\mathrm{n}, \%)^{*}$ & $69(81 \%)$ & 86 & 0.3751 & $77(87 \%)$ & $72(91 \%)$ & 0.3451 \\
\hline $\mathrm{pH}<7.10(\mathrm{n}, \%)^{* *}$ & $2(1.7 \%)$ & 0 & 0.1512 & 0 & 0 & \\
\hline $\mathrm{BE}<-12(\mathrm{n}, \%)^{* *}$ & $1(0.9 \%)$ & 0 & 0.3925 & $2(2,4 \%)$ & 0 & 0.2048 \\
\hline Apgar value at $5 \min <7(\mathrm{n}, \%)^{* *}$ & $1(0.9 \%)$ & $2(1.1 \%)$ & 1.0000 & 0 & 0 & \\
\hline Amniotomy $(\mathrm{n}, \%)^{* *}$ & $36(31.3 \%)$ & $44(24.4 \%)$ & 0.1962 & $19(23 \%)$ & $33(33 \%)$ & 0.1299 \\
\hline Peridural anaesthesia $(n, \%)^{* *}$ & $85(73.9 \%)$ & $126(70.0 \%)$ & 0.4676 & $15(18 \%)$ & $23(23 \%)$ & 0.4100 \\
\hline Oxytocin $(\mathrm{n}, \%)^{* *}$ & $73(63.5 \%)$ & $121(67.2 \%)$ & 0.5086 & $16(19 \%)$ & $24(24 \%)$ & 0.4380 \\
\hline Pathological CTG** & $20(17.4 \%)$ & $35(19.4 \%)$ & 0.6588 & $6(7 \%)$ & $8(8 \%)$ & 0.8421 \\
\hline Green amniotic fluid $(n, \%)^{* *}$ & $18(15.7 \%)$ & $6(3.3 \%)$ & 0.0002 & $7(8 \%)$ & 0 & 0.0035 \\
\hline Transfer to neonatal unit** & $28(24.3 \%)$ & $28(15.6 \%)$ & 0.0604 & $11(13 \%)$ & $9(9 \%)$ & 0.3615 \\
\hline Infantile infection $(\mathrm{n}, \%)^{* *}$ & $9(7.8 \%)$ & 0 & 0.0002 & $6(7 \%)$ & 0 & 0.0079 \\
\hline Postpartum endo(myo)metritis** & 0 & $1(0.6 \%)$ & 1.0000 & 0 & $1(1 \%)$ & 1.0000 \\
\hline
\end{tabular}

Table 4 Indications for the Caesarean section.

\begin{tabular}{|llll} 
& $\mathbf{2 0 1 3}$ & P value \\
\hline Primary Caesarean section & $\mathbf{2 0 1 2}$ & & \\
\hline - By request after failed induction & & $4(1.4 \%)$ & 0.0064 \\
\hline Secondary Caesarean section & $13(5.7 \%)$ & $67(23.0 \%)$ & 0.2293 \\
\hline - Obstructed labour in the dilatation stage & $43(18.7 \%)$ & $23(7.9 \%)$ & 0.1828 \\
\hline - Obstructed labour in the expulsion stage & $11(5.6 \%)$ & $29(43.3 \%)$ & 0.5681 \\
\hline Pathological CTC & $21(48.8 \%)$ & $6(9.0 \%)$ & 0.1384 \\
\hline - Pathological foetal blood analysis & $8(18.6 \%)$ & $2(3.0 \%)$ & 0.5194 \\
\hline - By request & 0 & $7(10.4 \%)$ & 0.7374 \\
\hline
\end{tabular}

immature cervix findings and thus confronted with unfavourable conditions. The combination of effective methods apears to have appeased this situation [12,15-17].

In the framework of the present study, we have investigated the clinical influence of the change in the methods of labour induction. In a comparison to 2012, the procedure was changed in 2013 in such a way the balloon catheters were routinely used for cervical ripening. In the absence of onset of labour the proce- dures are continued by oral administration of misoprostol. Furthermore, misoprostol is no longer given every 6 hours but rather every 4 hours in a somewhat higher dose - up to a maximum of three doses per day. In comparison to the previous year this procedure enables a more effective induction of labour. The rate of failed labour inductions was thus significantly reduced not only for first-time mothers but also for multiparous women. The rate of primary Caesarean sections due to failed induction of labour 
was also reduced. This advantage was not accompanied by a higher mortality. On the contrary, green amniotic fluid and infantile infections were seen less frequently.

The present study was a monocentric study and, of course, its valdity is thus limited, however it does provide useful clinical knowledge. On account of their strict study designs, randomised trials ensure that a procedure is standardised. In clinical routine deviations from standardised methods are not uncommon which can occasionally negate or weaken the effects demonstrated in the respective study. The present contribution reports the results of clinical work over a period of one year, which makes the findings appear to be even more relevant. The collectives are very well comparable. The paper deals with the induction of labour in one hospital by practically identical personnel and with similar demographic parameters. The Bishop score in 2013 was minimally higher but the difference was not clinically relevant. The rate of induction of birth at the mother's request was higher in 2013 because the indication for induction of labour had been more strictly applied. Thus, for example, induction of labour on suspicion of a non-diabetogenic foetal macrosomy is not evidence-based and this should no longer be considered as a reason for induction of labour [19]. When a patient is admitted to hospital with an indication for induction of labour that cannot be reproduced subsequently, the patient must then be informed that there is no evidence-based indication for labour induction. If the patient thereafter still insists upon induction of labour, this can be carried out at the patient's request - this explains the increase in this indication.

The efficacy of balloon catheters has been demonstrated and they are now being used more and more for this purpose in Germany. In some reports, it has been shown that, in particular, a combination with the most effective drug, misoprostol, is advantageous $[12,15-17]$. Not only their simultaneous use but also their sequential use show higher success rates for labour induction [1517].

Numerous studies have shown that when balloon catheters are employed oxytocin and peridural anaesthesia (PDA) find more frequent applications [12-14,20]. In these studies. however, it is not always clear whether oxytocin is used to induce labour or to support ccontractions. In many countries where balloon catheters are routinely used, induction is continued with oxytocin after withdrawal of the catheter. After removal of the balloon catheter, one often sees immature cervix findings and induction of labour with oxytocin under these circumstances is associated with a higher rate of surgical deliveries [9], thus, we use misoprostol in these cases. There is no routine administration of oxytocin or performance of PDA and so no influence on the rates of oxytocin and PDA use can be observed. This has also been mentioned in other studies $[15,16]$.

The rate of side effects was also lower. Thus, green amniotic fluid and infantile infections were also less frequent. It has be demonstrated that the use of balloon catheters does not have a higher side effect profile than the use of prostaglandins. Above all, overstimulations are less frequently seen and the total dose of prostaglandins is lower [12-14,21]. This may explain the lower incidence of green amniotic fluid. The lower frequency of infections may be due to the fact that, in contrast to the once only placement of the balloon catheter, the application of dinoprostone vaginal gel involves repeated vaginal manipulations. In their report, Jozwiak et al. also mentioned a higher rate of vaginal infections upon use of dinoprostone vaginal gel in comparison to the balloon catheter [22]. Misoprostol is generally administered orally as this form is considered to be safer and less stressful for the female patient $[10,11]$.

Van Baaren et al. have shown that induction of labour with a balloon catheter is more economical [23]; in comparison to the use of dinoprostone - either as vaginal gel or insert - the costs are not higher but rather lower.

Apart from the clinical course, the safety profile and economic points of view, the wishes of the patient with regard to the choice of method should be taken into consideration. Although it is well known that women favour the oral administration of misoprostol [10], only little is known about their opinions on the use of balloon catheters. Clinical experience indicates that the women are satisfied with this procedure. This impression has been confirmed by Pennell et al. who showed, among other factors, that the perceived pain was less in comparison to that from dinoprostone [24]. We have also previously reported that women found the use of not only oral misoprostol but also the balloon catheter to be satisfactory [25].

\section{Conclusions for Practice \\ $\nabla$}

Balloon catheters for the induction of labour are now established and effective. Their routine use in clinical practice leads to a more effective induction of labour, i.e., to fewer failed inductions of labour and fewer Caesarean sections due to failed induction of labour. These advantages are accompanied by a lower occurrence of green amniotic fluid and infantile infections.

\section{Conflict of Interest}

$\nabla$

Sven Kehl: speaker's fee, travel expenses (COOK Medical).

\section{References}

1 Rayburn WF, Zhang J. Rising rates of labor induction: present concerns and future strategies. Obstet Gynecol 2002; 100: 164-167

2 Koopmans CM, Bijlenga D, Groen $\mathrm{H}$ et al. Induction of labour versus expectant monitoring for gestational hypertension or mild pre-eclampsia after 36 weeks' gestation (HYPITAT): a multicentre, open-label randomised controlled trial. Lancet 2009; 374: 979-988

3 Boers KE, Vijgen SM, Bijlenga D et al. Induction versus expectant monitoring for intrauterine growth restriction at term: randomised equivalence trial (DIGITAT). BMJ 2010; 341: c7087

4 Riskin-Mashiah S, Wilkins I. Cervical ripening. Obstet Gynecol Clin North Am 1999; 26: 243-257

5 Cocks DP. Significance of initial condition of cervix uteri to subsequent course of labour. Br Med J 1955; 1: 327-328

6 Bishop EH. Pelvic scoring for elective induction. Obstet Gynecol 1964; 24: $266-268$

7 Gonen R, Degani S, Ron A. Prediction of successful induction of labor: comparison of transvaginal ultrasonography and the Bishop score. Eur J Ultrasound 1998; 7: 183-187

8 Kehl S. Geburtseinleitung. Geburtsh Frauenheilk 2014; 74: R41-R54

9 Alfirevic Z, Kelly AJ, Dowswell T. Intravenous oxytocin alone for cervical ripening and induction of labour. Cochrane Database Syst Rev 2009; 4: CD003246

10 Alfirevic Z, Weeks A. Oral misoprostol for induction of labour. Cochrane Database Syst Rev 2006; 2: CD001338

11 Hofmeyr GJ, Gülmezoglu AM, Pileggi C. Vaginal misoprostol for cervical ripening and induction of labour. Cochrane Database Syst Rev 2010; 10: CD000941

12 Jozwiak M, Bloemenkamp KW, Kelly AJ et al. Mechanical methods for induction of labour. Cochrane Database Syst Rev 2012; 3: CD001233

13 Fox NS, Saltzman DH, Roman AS et al. Intravaginal misoprostol versus Foley catheter for labour induction: a meta-analysis. BJOG 2011; 118: 647-654 
14 Vaknin Z, Kurzweil Y, Sherman D. Foley catheter balloon vs. locally applied prostaglandins for cervical ripening and labor induction: a systematic review and metaanalysis. Am J Obstet Gynecol 2010; 203: 418-429

15 Kehl S, Ehard A, Berlit S et al. Combination of misoprostol and mechanical dilation for induction of labour: a randomized controlled trial. Eur J Obstet Gynecol Reprod Biol 2011; 159: 315-319

16 Ande $A B$, Ezeanochie $C M$, Olagbuji NB. Induction of labor in prolonged pregnancy with unfavorable cervix: comparison of sequential intracervical Foley catheter-intravaginal misoprostol and intravaginal misoprostol alone. Arch Gynecol Obstet 2012; 285: 967-971

17 Hill JB, Thigpen BD, Bofill JA et al. A randomized clinical trial comparing vaginal misoprostol versus cervical Foley plus oral misoprostol for cervical ripening and labor induction. Am J Perinatol 2009; 26: 33-38

18 AWMF-Leitlinie 015/032 (S1). Standards zur Ultraschalluntersuchung in der Frühschwangerschaft. August, 2010. Online: http://www.dggg. de/leitlinienstellungnahmen/archivierte-leitlinien/federfuehrendeleitlinien-der-dggg/?eID=dam_frontend_push\&docID=2068; last access: 30.03 .2015

19 Chauhan SP, Grobman WA, Gherman RA et al. Suspicion and treatment of the macrosomic fetus: a review. Am J Obstet Gynecol 2005; 193 : 332-346
20 Cromi A, Ghezzi F, Uccella $S$ et al. A randomized trial of preinduction cervical ripening: dinoprostone vaginal insert versus double-balloon catheter. Am J Obstet Gynecol 2012; 207: 125.e1-125.e7

21 Kehl S, Ziegler J, Schleussner E et al. Sequential use of double-balloon catheter and oral misoprostol versus oral misoprostol alone for induction of labour at term (CRBplus trial): a multicentre, open-label randomised controlled trial. BJOG 2015; 122: 129-136

22 Jozwiak M, Oude Rengerink $K$, Benthem $M$ et al. Foley catheter versus vaginal prostaglandin E2 gel for induction of labour at term (PROBAAT trial): an open-label, randomised controlled trial. Lancet 2011; 378: 2095-2103

23 van Baaren GJ, Jozwiak M, Opmeer BC et al. Cost-effectiveness of induction of labour at term with a Foley catheter compared to vaginal prostaglandin E(2) gel (PROBAAT trial). BJOG 2013; 120: 987-995

24 Pennell CE, Henderson JJ, O'Neill MJ et al. Induction of labour in nulliparous women with an unfavourable cervix: a randomised controlled trial comparing double and single balloon catheters and PGE2 gel. BJOG 2009; 116: 1443-1452

$25 \mathrm{Kehl}$ S, Welzel G, Ehard A et al. Women's acceptance of a double-balloon device as an additional method for inducing labour. Eur J Obstet Gynecol Reprod Biol 2013; 168: 30-35 